\title{
Seafood Without the Sea: Article 20 of the Agreement on Trade-Related Aspects of Intellectual Property Rights, the 'Justifiability Test' and Innovative Technologies in a Sustainable Blue Economy
}

\author{
Mariela de Amstalden \\ University of Birmingham, Birmingham, United Kingdom \\ m.deamstalden@bham.ac.uk
}

\begin{abstract}
With the growing global demand for seafood and ocean ecosystems increasingly at risk, advances in the field of cellular aquaculture provide a unique opportunity to foster sustainable fisheries. However, the successful commercialization of cell-based seafood requires the adoption of the regulation on product labelling. This article explores the trademarks issues of cell-based foods specifically and whether these types of intellectual property rights can contribute to the promotion of sustainable fisheries in the so-called 'blue economy'. It examines the extent to which international trademark protection has the ability to contribute to better ocean governance by accommodating higher public policy imperatives, the recent case law on Article 20 of the Agreement on Trade-Related Aspects of Intellectual Property Rights, and the newly adopted 'justifiability test' for special requirements as they apply to trademarks. It appraises some of the legal implications for the regulatory design of domestic labelling regulation as they apply to cell-based seafood.
\end{abstract}

\section{Keywords}

Agreement on Trade-Related Aspects of Intellectual Property Rights - cell-based technology - justifiability test - labelling - sustainable blue economy - trademarks 


\section{The Sustainable Blue Economy, Innovation Law and Intellectual Property Rights}

Seafood without the sea is now a reality, with latest estimations forecasting cell-based seafood to be available for sale directly to consumers as early as 2022. ${ }^{1}$ With growing global demand for seafood and ocean ecosystems increasingly at risk, advances in the field of cellular aquaculture provide a unique market-based solution to promote sustainable fisheries. Conversely, transitioning from 'blue growth' 2 to a 'sustainable blue economy' that is socially equitable, environmentally sustainable and economically viable ${ }^{3}$ will require a paradigm shift, whereby the environment and the economy are not in conflict, but intrinsically linked to each other. ${ }^{4}$ Likewise, the transformation of the 'blue economy' in the immediate future will also require considerable investment in sustainable value chains, primarily through innovative, emerging technologies, such as cellular aquaculture and its cell-based products. ${ }^{5}$

Promoted as a sustainable alternative that reduces bycatch, habitat damage and the environmental footprint of fishing vessels' fuel usage, seafood produced using animal cell-cultivation technology (cell-based seafood) offer an intriguing chance to improve ocean governance while addressing challenges associated with climate change, public health and animal welfare. ${ }^{6}$ The applications for this technology are numerous and range from livestock and poultry to fish and seafood. ${ }^{7}$ In essence, cell-based seafood is produced by tissue and

1 Most recently, Will Bedingfield, 'Lab-Grown Tuna Steaks Could Reel in Our Overfishing Problem' (Wired UK, 23 March 2021) <www.wired.co.uk/article/blue-nalu-lab-grown-fish>; Harrison Tasoff, 'Would Cell-Based Seafood Actually Benefit Conservation?' (Futurity USA, 26 February 2021) <www.futurity.org/cell-based-seafood-conservation-benefits-2524432-2/> both accessed 22 December 2021.

2 Other innovative technologies also play a critical role in this transition, like artificial intelligence, blockchain and autonomous vehicles, see European Commission, 'Blue Growth Opportunities for Marine and Maritime Sustainable Growth' (13 September 2012) $\mathrm{COM} / 2012 / 494$ final.

3 Nathan Bennett and others, 'Towards a Sustainable and Equitable Blue Economy' (2019) 2 Nature Sustainability 991-93; Andrés Cisneros-Montemayor, 'Enabling Conditions for an Equitable and Sustainable Blue Economy' (2021) 591 Nature 396-401.

4 ibid 396.

5 European Commission, 'A New Approach for a Sustainable Blue Economy in the EU: Transforming the EU's Blue Economy for a Sustainable Future' (17 May 2021) COM/2021/24O final.

6 Natalia Rubio and others, 'Cell-Based Fish: A Novel Approach to Seafood Production and an Opportunity for Cellular Agriculture' (2019) 3(43) Frontiers in Sustainable Food Systems 1, 1.

7 Among others, Jens Schovsbo and Thomas Riis, 'Public Policy Limitations on Trademark Subject Matter' in Irene Calboli and Jane C Ginsburg (eds), The Cambridge Handbook of International and Comparative Trademark Law (CUP 2020) 241-54. 
bioprocess engineering that result in a product that is molecularly identical to conventional seafood. To put it into context, current estimations suggest that ocean biomass content has been lowered by up to $80 \%$ due to industrialized fisheries and marine capture. ${ }^{8} \mathrm{~A}$ healthy ocean, and the resources it provides to mankind, are critical to guarantee life on this planet and the ability of human societies to sustain themselves. ${ }^{9}$ Findings paths to alleviate pressure on fisheries at the global scale is essential to enable the recovery of marine environments and protecting the integrity of oceans. ${ }^{10}$ Equally, a transition to a sustainable blue economy will also promote responsible food systems by choosing alternative sources of food and feed, like cell-based seafood. ${ }^{11}$ As a result, leading cell-based seafood start-ups sustain that they are not developing products to replace the traditional seafood industry. ${ }^{12}$ Rather, they aim at becoming a sustainable third alternative for seafood consumers, along wild fisheries and traditional aquaculture, thereby strengthening the overall seafood system. ${ }^{13}$

However, if recent regulatory activity about cell-based meats as well as strategic trademark litigation are any indication, ${ }^{14}$ labelling of seafood produced

8 Ransom Myers and Boris Worm, 'Rapid Worldwide Depletion of Predatory Fish Communities' (2003) 423 Nature 280.

$9 \quad 2030$ Agenda for Sustainable Development, Sustainable Development Goal 14: Conserve and Sustainably Use Oceans, Seas and Marine Resources for Sustainable Development $<$ https://sdgs.un.org/goals/goalı4> accessed 22 December 2021.

10 Natalia Serpetti and others, 'Impact of Ocean Warming on Sustainable Fisheries Management Informs the Ecosystem Approach to Fisheries' (2017) 7 Scientific Reports $<$ https://doi.org/10.1038/s41598-017-13220-7> accessed 22 December 2021. For an ecofeminist approach to the protection of oceans, see Raquelyn Jumawan-Dadang, 'Saving Marine Life: An Empirical Assessment of Ecofeminist Thought in Coastal Communities' (2015) 63 Phillippine Sociological Review 61-83.

11 European Commission (n 5) 8-10.

12 At the moment of writing, the leading cell-based seafood start-ups are: BlueNalu (United States) which cultivates seafood, Shiok Meats (Singapore) which cultivates shrimp, and Avant Meats (Hong Kong) which cultivates fish fillet.

13 Alliance for Meat, Poultry and Seafood Innovation, 'Response to the US Food and Drug Administration (FDA) Request for Information on the Labelling of Foods Comprised of or Containing Cultured Seafood Cells' (8 March 2021) <www.regulations.gov/comment/ FDA-2020-N-1720-0022> accessed 22 December 2021.

14 For example, see the US Cattlemen's Association petition to the Federal Drug Administration (FDA), stating that: "The labels "beef" or "meat" should inform consumers that the product is derived naturally from animals as opposed to alternative proteins such as plants and insects or artificially grown in a laboratory. (These alternative products) should thus not be permitted to be labelled as ... "meat", which is understood to be derived from animal tissue or flesh for use as food.' US Cattlemen's Association, Petition for the Imposition of Beef and Meat Labeling Requirements: To Exclude Products Not 
using cell-cultivation technology is likely to become contentious with the established billion-dollar fish industry. How will the new food call itself, or be allowed to call itself? Are regulatory frameworks well-equipped to address the terminological challenges encountered posed by these novel foods? Because labelling through trademarks is key to product differentiation, names have significant impact on market acceptance and, ultimately, the ability of these novel foods to generate societal benefits. ${ }^{15}$

Through the lens of trademark theory, this paper examines some of the legal implications of cell-based seafood labelling. The main hypothesis posited here is twofold: (1) at the domestic level, food labels that include terms with a defined legal meaning in national regulation pose a higher litigation risk and thus, should be used with caution in trademarks, and (2) at the international level, special requirements that encumber on the exercise of trademark rights could be adopted to the extent that their ultimate aim is to address exceptionally grave global problems - like climate change mitigation. This discussion is timely, because trademarks are often portrayed as incompatible with the pursue of certain public policy imperatives, ${ }^{16}$ and contentious, in that they have the potential and ability to restrain public regulators from adopting measures aimed at, for example, the transition towards a sustainable blue economy, creating a 'regulatory chill'.17 Drawing lessons from WTO disputes regarding the labelling of tobacco products in Australia - Plain Packaging, ${ }^{18}$ this paper

Derived Directly from Animals Raised and Slaughtered from the Definition of "Beef" and "Meat"' (9 February 2018) <www.fsis.usda.gov/sites/default/files/media_file/2020 -o7/18-o1-Petition-US-Cattlement-Associationo2og18.pdf> accessed 22 December 2021.

15 Cristopher Bryant and Courtney Dillard, 'The Impact of Framing on Acceptance of Cultured Meat' (2019) 6 Frontiers in Nutrition $103<$ https://doi.org/10.3389/fnut.2019 .00103> accessed 22 December 2021.

16 Among others Kristy Buzard and Tania Voon, 'How Trade-Restrictive Is Standardized Packaging?: Economic and Legal Implications of the WTO Panel Reports in “Australia-Tobacco Plain Packaging"' (2020) 19(2) WTR 267-81; Tania Voon and Andrew Mitchell, Public Health and Plain Packaging of Cigarettes: Legal Issues (Edward Elgar 2014).

17 Among others, Oleksandra Vytiaganets, 'Smoking Chills? Tobacco Regulatory Chill, Foreign Investment, and the NCD Crisis in the Post-Soviet Space: A Case Study from Ukraine' (2020) 21 JWIT 753-80; Kyla Tienhaara, 'Regulatory Chill in a Warming World: The Threat to Climate Policy Posed by Investor-State Dispute Settlement' (2018) 7(2) TEL 229-50.

18 WTO, Australia: Certain Measures Concerning Trademarks, Geographical Indications and Other Plain Packaging Requirements Applicable to Tobacco Products and Packaging, Report of the Panel (28 June 2018) WTO/DS467/R; WTO, Australia: Certain Measures Concerning Trademarks, Geographical Indications and Other Plain Packaging Requirements Applicable to Tobacco Products and Packaging, Report of the Appellate Body (9 June 2020) WTO/ $\mathrm{DS}_{435} / \mathrm{AB} / \mathrm{R}$. 
focuses on the scarce use in litigation of Article 20 of the WTO Agreement on Trade-Related Aspects of Intellectual Property Rights (TRIPS) ${ }^{19}$ and its latest de novo interpretation, which reconciles the rights conferred to trademark owners to extract economic value with the right of States to pursue and attain public policy objectives.

The paper is structured as follows. Section 2 introduces the concept of cellbased meats and identifies how novel products are located and addressed within the legal discourse. Section 3 frames the labelling of cell-based meats as a trademark issue, paying particular attention to the functionality of trademarks under general trademark theory. Section 4 examines the de novo interpretation of Article 20 TRIPS that led to the newly established 'justifiability test' after Australia - Plain Packaging. Section 5 engages in a discussion about the potential application of Article 20 TRIPS for the labelling of cell-based meats, questioning substantive trademark law's ability to contribute to a sustainable blue economy. Section 6 briefly concluding.

\section{Not Just Mere Semantics: Ontological Challenges to Regulating Cell-Cultivated Products}

As a general rule, legal systems are vested with the ability to create parameters that will determine whether and to what extent positive societal change will happen. ${ }^{20}$ Recent developments in the regulation of conventional meat products and its cell-based counterparts provide a critical blueprint to assess the impact of labelling measures for cell-based seafood. More specifically, debates about the ontological challenges of determining whether cell-based meats are considered 'meat' merit an in-depth legal analysis, not least because the complexity harboured in the concept of 'meat' is compounded by fundamental jurisdictional differences across the globe.

At present, a few terms are used to describe meats produced using cellular technologies: 'cell-based', 'lab-grown', 'cultured', 'clean', 'slaughter-free..21 The

19 WTO Agreement on Trade-Related Aspects of Intellectual Property Rights (15 April 1994) Marrakesh Agreement Establishing the World Trade Organization (entered into force 1 January 1995) 1867 UNTS 299, Annex 1C (TRIPS).

20 Klaus Bosselmann, The Principle of Sustainability: Transforming Law and Governance (2nd edn, Routledge 2017) 43.

21 Raychel E Santo and others, 'Considering Plant-Based Meat Substitutes and CellBased Meats: A Public Health and Food Systems Perspective' (2020) Frontiers in Sustainable Food Systems <https://www.frontiersin.org/articles/10.3389/fsufs.2020.00134/full> accessed 22 December 2021; William K Hallman and William K Hallman II, 'An Empirical 
terminological confusion reflects the differing views that try to find space (and are fighting for definitional supremacy) within a novel discourse. ${ }^{22}$ The language used within the law will thus undoubtedly have social, economic, political and cultural consequences for the future of the global food system.

Yet it is often the case that technological advancements precede existing rules-based regulation. ${ }^{23}$ This notoriously difficult 'pacing problem' ${ }^{24}$ is also present in the laws and regulations potentially applicable to animal cellcultivated products, posing yet another example ${ }^{25}$ of the challenges encountered by the lack of responsive regulation. ${ }^{26}$ Regulatory (un)certainties that incentivise carbon-negative technologies are an important economic factor for the successful commercialization of cell-based products. Such biotechnological innovations call for legal predictability in view of continuous shifting in consumer preferences that favour sustainable products.

\subsection{Cell-Based Food Products in the Legal Discourse}

It was 1931 when Winston Churchill envisioned cell-based meats. In a line perhaps more suitable to science fiction writing at the time, he declared that: '(w)e shall escape the absurdity of growing a whole chicken in order to eat the breast or wing, by growing these parts separately under a suitable medium.' ${ }^{27}$ Almost a hundred years later, it seems reality keeps topping fiction.

Cell-based meat is meat produced by tissue and bioprocess engineering that results in a product that is molecularly identical to conventional meats. ${ }^{28}$ Its process includes the isolation and propagation of steam cells, identification

Assessment of Common or Usual Names to Label Cell-Based Seafood Products' (2020) 85(8) Journal of Food Science 2267-77.

22 Vito De Lucia, 'Competing Narratives and Complex Genealogies: The Ecosystem Approach in International Environmental Law' (2015) 27 Journal of Environmental Law 91, 101.

23 Analysing the shift from a rules-based approach towards a principled-based regulatory regime in the technology sector, and its impact on global trade: Shin-Yi Peng, "The Rule of Law in Times of Technological Uncertainty: Is International Economic Law Ready for Emerging Supervisory Trends?' (2019) 22(1) JIEL 1-27.

24 Gary Marchant, 'The Growing Gap Between Emergent Technologies and the Law' in Gary Marchant, Braden Allenby and Joseph Herckert (eds) The Growing Gap Between Emergent Technologies and Legal-Ethical Oversight: The Pacing Problem (Springer 2011) 19-33.

25 Alongside the information and communications technology (ICT); Peng (n 10).

26 Netta Barak-Corren and Yael Kariv-Teitelbaum, 'Behavioral Responsive Regulation: Bringing Together Responsive Regulation and Behavioral Public Policy' (2021) Regulation and Governance 1-21.

27 Winston Churchill and Steven Spurrier, 'Fifty Years Hence' (1931) 83(492) Strand Magazine.

28 Neil Stephens and others, 'Bringing Cultured Meat to Market: Technical, Socio-Political, and Regulatory Challenges in Cellular Agriculture' (2018) 78 Trends in Food Science and Technology $155^{-66 .}$ 
and modification of sustainable biomaterials, and the design of co-culture systems with various cell types, such as muscle and fat cells. ${ }^{29}$ The process involves in vitro production of specific muscle, fat, and connective tissues. ${ }^{30}$ Cell-based meats were initially envisaged in 2002 by NASA-funded scientists as a means to simplify space travel by reducing the amount of supplies taken in a shuttle for multi-years space voyages. ${ }^{31}$ These efforts were followed by doctoral research funded in the Netherlands, which culminated when Mark Post, a professor at Maastricht University, unveiled the first cultured beef burger that was cooked and eaten in a London press conference back in $2013 .{ }^{32}$ Unlike poultry and red meat, seafood encompasses more than 200 edible species, which could in turn appear to be an attractive opportunity for growth as companies diversify their products to meet consumer demand. As matters presently stand, there is considerable financial investment in cell-based meats, thus substantially contributing to technological maturity and commercial readiness in the field. ${ }^{33}$ Although no cell-based seafood is on the market at the time of writing, Singapore recently approved cell-based chicken for sale and consumption within its territory, pioneering a regulatory pathway for other cell-based products. ${ }^{34}$ It is expected that other jurisdictions, such as the United States, ${ }^{35}$

29 Mark Post, 'Cultured Meat from Stem Cells: Challenges and Prospects' (2012) 92 Meat Science 297-301 <https://doi.org/10.1016/j.meatsci.2012.04.008> accessed 22 December 2021.

$30 \quad$ Tom Ben-Arye and Schulamit Levenberg, 'Tissue Engineering for Clean Meat Production' (2019) Frontiers of Sustainable Food Systems 3-46 <https://doi.org/10.3389/fsufs .2019.00046> accessed 22 December 2021.

31 And to also facilitate the colonization of distant planets, see MA Benjaminson, J Gilchriest and M Lorenz, 'In Vitro Edible Muscle Protein Production System (MPPS): Stage 1, Fish' (2002) 51(12) Acta Astronautica 879-89.

32 Mark Post, 'Cultured Beed: Medical Technology to Produce Food' (2014) 94 Journal of the Science Food and Agriculture 297-301.

33 The Good Food Institute, 'An Ocean of Opportunity: Plant-Based and Cell-Based Seafood for Sustainable Oceans Without Sacrifice' (22 January 2019) Action Paper <https:// gfi.org/wp-content/uploads/2021/o1/GFI_An_Ocean_of_Opportunity.pdf > accessed 22 December 2021.

34 Singapore Food Agency (SFA), 'Safety of Alternative Proteins' (10 December 2020) < www .sfa.gov.sg/food-information/risk-at-a-glance/safety-of-alternative-protein $>$ accessed 22 December 2021.

35 At the federal level in the United States, the Food and Drug Administration (FDA) and the Department of Agriculture (USDA) have formally agreed to jointly regulate cell-based meats: Formal Agreement Between FDA and USDA Regarding Oversight of Human Food Produced Using Animal Cell Technology Derived from Cell Lines of USDA-Amenable Species (7 March 2019) <www.fda.gov/food/domestic-interagency-agreements-food/ formal-agreement-between-fda-and-usda-regarding-oversight-human-food-produced -using-animal-cell > accessed 1 December 2020. For a chronological timeline of regulatory 
but also the European Union, ${ }^{36}$ will move towards the adoption of new regulation for cell-based products in the near future.

\subsection{Competing Narratives in the Legal Discourse of Cell-Based Foods}

Against this backdrop, a few competing narratives have emerged in the legal discourse surrounding cell-based meats. ${ }^{37}$ These narratives, with their irreducible normative elements, have the potential to impactfully inform ongoing contentious debates. ${ }^{38}$ At present, considerations about the expected benefits of market access for cell-based meats are primarily articulated in the language of climate change mitigation ('better for the world'), ${ }^{39}$ and its positive effect on other related global challenges, such as food safety and security ('feeding the world'), ${ }^{40}$ and animal welfare ('eat meat not animals') ${ }^{41}$ We turn to explore these below.

\subsection{1 'Better for the World': On Environmental Considerations}

One of the main reasons driving the development and commercialization of cell-based meats has been their potential to mitigate climate change by reducing greenhouse gas emission (GHGs) and limiting the use of water and land. ${ }^{42}$ Indeed, climate change considerations and the quest for sustainable food consumption have been dominating the discourse around the acceptance and desire to purchase cell-based meats, as conventional meat production is increasingly associated with large numbers of GHG s that significantly contribute to anthropogenic climate change. ${ }^{43}$

Although research to date suggests that many of the purported environmental and health benefits of cell-based meat are largely speculative, ${ }^{44}$ there is a

developments in the United States: Joel Greene and Sahar Anga-Djivand, 'Regulation of Cell-Cultured Meat' (Congressional Research Service, 5 October 2018) In Focus <https:// fas.org/sgp/crs/misc/IF10947.pdf > accessed 22 December 2021.

36 As matters stand at the time of writing, cell-based meats are considered novel foods under EU law, and thus the Novel Food Regulation applies: Regulation (EU) No 2015/2283 on Novel Foods (11 December 2015) OJ L327.

37 Alexandra Sexton, Tara Garnett and Jamie Lorimer, 'Framing the Future of Food: The Contested Premises of Alternative Proteins' (2019) Nature and Space 1, 6.

38 Nicolas Lamp, 'How Should We Think About the Winners and Losers from Globalization? Three Narratives and Their Implications for the Redesign of International Economic Agreements' (2019) 30(4) EJIL 1359, 1361.

39 Sexton, Garnett and Lorimer (n 37$) 1$.

40 ibid.

41 ibid.

42 Stephens and others (n 28) 157.

43 ibid 158.

44 Santo and others (n 21) 134. 
degree of certainty about the potential for positive contribution of cell-based meats. As an alternative, cell-based meats production aims at reducing emissions per unit of meat produced by avoiding the biological process of a whole animal. ${ }^{45}$ Several studies have been conducted to assess the potential environmental benefits of cultured meat, with the overall conclusion being that it could indeed have less environmental impact than beef. ${ }^{46}$ Still, some controversy surrounding the actual effects of cultured meat production on climate change mitigation remains, as its effective GHG emissions will largely depend on the type of production systems and growth media chosen, which at the moment are still in development. ${ }^{47}$

\subsection{2 'Feeding the World': On Food Security and Safety Considerations}

Regular consumption of seafood has been associated with numerous health benefits, including a reduced risk of cardiovascular disease in adults and improved cognitive development during gestation and infancy. ${ }^{48}$ At present however, there is not enough seafood available for the global population to consume at the recommended levels to warrant the noted health benefits. ${ }^{49}$ Hence, an additional reason behind the proliferation of cell-based meats is its potential to sustainably feed the growing global population. According to the Food and Agriculture Organization of the United Nations (FAO), the world population is expected to reach 9.7 billion in $2050,{ }^{50}$ which will, in turn, require agricultural output to double the food, feed and biofuel produced in 2012.51 Conversely, economic growth has accelerated dietary transitions, translating in increased meat consumption - with severe implications for the sustainable use of resources. ${ }^{52}$ Against this backdrop, cell-based meats understood as a potential solution to world hunger builds the foundation for the main message in the second promissory narrative of 'feeding the world. ${ }^{53}$ Through this lens,

\footnotetext{
45 Stephens and others ( $\mathrm{n} 28) 157-58$.

46 ibid 158 .

47 John Lynch and Raymond Pierrehumbert, 'Climate Impacts of Cultured Meat and Beef Cattle' (2019) 3(5) Frontiers of Sustainable Food Systems <https://doi.org/10.3389/fsufs .2019.00005> accessed 22 December 2021.

48 Santo and others (n 21) 3 (with further references).

49 ibid.

50 Food and Agriculture Organisation (FAO), 'The Future of Food and Agriculture: Trends and Challenges' (2018) 9 <www.fao.org/3/a-i6881e.pdf> accessed 22 December 2021.

$51 \quad$ ibid 21.

$5^{2}$ ibid 10.

53 Sexton, Garnett and Lorimer (n 37) 8-9.
} 
food security is warranted with a 'village-scale production'54 that increases efficiencies at the local level while ensuring critical economic and physical access to nutritious food. ${ }^{55} \mathrm{~A}$ market shift from farmed to cell-based meats would involve a significant transformation in the supply chains of animal protein production, with biologists and engineers largely replacing farmers and meat processors. ${ }^{56}$

In a similar vein, it is now understood that industrial animal agriculture and aquaculture pose severe threats to public health due to the spread of antibiotic resistance in live animals, ${ }^{57}$ as well as the increasing recurrence of food-borne diseases caused by bacterial pathogens such as E. coli and Salmonella. ${ }^{58} \mathrm{In}$ addition, animal agriculture and aquaculture as a threat to public health has gained renewed focus in light of the COVID-19 pandemic due to their inherent intense exposure to zoonotic pathogens. ${ }^{59}$ It is now known that zoonoses can spread in two distinct ways: in cases where different species are kept open next to one another (as in so-called 'wet markets') allowing zoonosis to spread from host species, or through livestock to infected by local wild birds and bats that can interact with animals raised for food. ${ }^{60}$ To put it into perspective, about $70 \%$ of new diseases affecting humans over the past ten years originated from animals or products of animal origin. ${ }^{61}$ Indeed, close interactions between the health of humans, animals, and the environment can lead to a deadly

54 Cor Van Der Weele and Johannes Tramper, 'Cultured Meat: Every Village Its Own Factory?' (2014) 32(6) Trends in Biotechnology 294-96 <http://dx.doi.org/10.1016/j.tibtech.2014 .04.009> accessed 22 December 2021.

55 Margot Pollans, 'Food Systems' in Michael Burger and Justin Gundlach (eds), Climate Change, Public Health and the Law (CUP 2018) 266, 268.

$56 \quad$ Santo and others (n 21) 14 (with further references).

57 Sghaier Chriki and Jean-Francois Hocquette, 'The Myth of Cultured Meat: A Review' (2020) 7(7) Frontiers in Nutrition 1-9 <https://doi.org/10.3389/fnut.2020.00007> accessed 22 December 2021; Santo and others (n 21) 3.

58 Chriki and Hocquette ( $\left.\mathrm{n}_{57}\right)_{3}$.

59 Santo and others (n 21) 3; Jan Dutkiewicz, Astra Taylor and Troy Vettese, 'The Covid-19 Pandemic Shows We Must Transform the Global Food System' (The Guardian, 16 April 2020) <www.theguardian.com/ commentisfree/2020/apr/16/coronavirus-covid-19-pande mic-food-animals>; Olivier Restif, 'Coronavirus: Three Misconceptions About How Animals Transmit Diseases Debunked' (The Conversation UK, 16 April 2020) <https:// theconversation.com/coronavirus-three-misconceptions-about-how-animals-transmit -diseases-debunked-134485 $>$ both accessed 22 December 2021.

6o World Organisation for Animal Health (OIE) Press Release, 'Emerging and Re-Emerging Zoonoses' (14 April 2019) <www.oie.int/en/for-the-media/editorials/detail/article/ emerging-and-re-emerging-zoonoses/> accessed 22 December 2021.

61 John Amuasi and others, 'Emerging Zoonosis: A One Health Challenge' (2020) 395 The Lancet 1543-44 <https://doi.org/10.1016/So140-6736(20)31028-X> accessed 22 December 2021. 
pandemic. ${ }^{62}$ Because cultured meat is not produced from animals raised in a confined space, ${ }^{63}$ the risk of a zoonotic outbreak is nearly eliminated.

\subsection{3 'Eat Meat, Not Animals': On Animal Welfare Considerations}

Recent studies have shown that consuming meats without having to first slaughter an animal is becoming increasingly appealing to the average consumer. ${ }^{64}$ While a complete shift to veganism is presently unlikely, ${ }^{65}$ public (and legal) perceptions about the general tolerance for animal suffering has been shifting. ${ }^{66}$ There is a growing number of meat consumers that prefer their meat consumption not to be associated with moral or animal welfare issues. ${ }^{67}$ However, some criticism remains about cell-based meat as a means to reduce animal suffering, because the technology does not challenge the structural status quo, and animals remain commodities - albeit of a distinctly different nature. ${ }^{68}$ This line of thought calls into question whether law and culture around meat are indeed shifting - or whether the shift is illusory, as the current legal hierarchy remains unchallenged. ${ }^{69}$ It further raises ethical issues, posing questions about the moral status of animals, whether some animals have attained a higher status than others and how legitimate is that distinction. ${ }^{70}$

\footnotetext{
62 ibid 1544.

63 Chriki and Hocquette ( $\left.\mathrm{n}_{57}\right) 3$.

64 Numerous reasons have been identified behind the desire to consume meat in general, not least cultural and religious: Hope Johnson, "From "Meat Culture" to "Cultured Meat": Critically Evaluating the Contested Ontologies and Transformative Potential of Bio-Fabricated Animal Material on Culture and Law' (2019) 22(2) Media and Culture Journal <https://doi.org/10.5204/mcj.1504> accessed 22 December 2021.

65 Jeff Sebo, 'The Ethics and Politics of Plant-Based and Cultured Meat' (2018) 13(1) The Ethics Forum 159-83, 164 .

66 On sentience as a legal standard to determine animal rights under the law, see Charlotte Blattner, 'The Recognition of Animal Sentience by the Law' (2019) 9(2) Journal of Animal Ethics 121-36. Also Lieve Van Woensel, 'What if We Didn't Need Cows for Our Beef?' (European Parliament Think Tank, Scientific Foresight Unit, July 2019) <www.europarl .europa.eu/RegData/etudes/ATAG/2019/634446/EPRS_ATA(2019)634446_EN.pdf> accessed 22 December 2021.

67 Creating what it is now known as the 'meat paradox': Benjamin Buttlar and Eva Walther, 'Measuring the Meat Paradox: How Ambivalence Towards Meat Influences Moral Disengagement' (2018) 128 Appetite $15^{2-58}$.

68 Angela Lee, 'Meat-ing Demand: Is In Vitro Meat a Pragmatic, Problematic, or Paradoxical Solution?' (2018) 30(1) Canadian Journal of Women and the Law 1, 8, 21; Johnson (n 61) 1-2. 69 ibid.

70 ibid.
} 


\subsection{Narratives and Labelling Regulation}

These three competing narratives operate in diverse legal frameworks that, to varying extents, serve or hinder the realization of the promises they portray. Conversely, the collision of realities these narratives create have the ultimate aim of obtaining a place of dominance within the legal discourse to command the view of a majority about what is understood as 'meat'. The need to undo the damage caused by industrialized animal farming is undisputed; whether cell-based meats as the lead alternative protein ${ }^{71}$ will be part of the solution to tackle climate change remains to be seen. Likewise, cell-based meat appears to be more efficient in guaranteeing food safety, while at the same time providing an avenue to consistency and reliability in terms of quality and performance ${ }^{72}$ - characteristics that will play an essential role in establishing the level of distinctiveness between cell-based and conventional meat products. Furthermore, the narrative about cell-based meats as a product for mass consumption of alternative proteins to improve animal welfare fits well within the discourse about minimising or indeed eliminating ethical considerations about industrial animal faming. This last narrative warrants further consideration for illustrative purposes. We elaborate below.

\subsection{Labelling Regulation and Trademarks}

Concerned nonetheless that animal welfare considerations will lead consumers towards cell-based meat, ${ }^{73}$ the US conventional meat industry lobbied in favour of the adoption of meat labelling measures that 'exclude(s) products not derived directly from animals born, raised, harvested and processed in the traditional way, regardless of their country of origin. ${ }^{74}$ The argument does not appear to challenge the legitimacy of technologies involved in the process of producing cultured meat. Instead, it focuses on the result enabled by those technologies, and deems the end product unfit for purpose, that is, outside the scope of what shall be considered 'meat'. As the US Cattlemen's Association petitioned to the FDA:

The labels 'beef' or 'meat' should inform consumers that the product is derived naturally from animals as opposed to alternative proteins such

\footnotetext{
71 Also World Wide Fund for Nature, 'Enhancing Nationally Determined Contributions (NDCs) for Food Systems: Recommendations for Decision-Makers' (August 2020) <https://wwfeu.awsassets.panda.org/downloads/wwf_ndc_food_final_low_res.pdf> accessed 22 December 2021.

72 Sexton, Garnett and Lorimer (n 37$) 11$.

73 Sebo (n 65) 162.

74 US Cattlemen's Association (n 14).
} 
as plants and insects or artificially grown in a laboratory. (This alternative products) should thus not be permitted to be labelled as (...) 'meat', which is understood to be derived from animal tissue or flesh for use as food. ${ }^{75}$

This premise seeks to position the legal debate about what is meat within the natural vs artificial binary to establish a dominant ontology of meat ${ }^{76}$ : What constitutes actually meat? Who determines it? Why does it matter? Arguably, the concept of 'meat' is deeply embedded in personal, social and cultural beliefs about its role in our diets, ${ }^{77}$ since its consumption has the ability to convey a specific message defined by time and space. ${ }^{78}$ It follows that what it is legally understood as 'meat' will reflect and legitimize a particular social reality ${ }^{79}$ and the values that underlie it. As such, legislation on compositional food standards cannot exist without a tangible food quality concept, which in turn has to continuously adapt to new consumer demands. ${ }^{80}$ This rationale applies to other cell-based meats, too. As way of illustration, consider for a moment the use of the trademark 'cellular aquaculture' on the labelling of (yet to be commercialised) cell-based seafood. ${ }^{81}$ Now consider the trademark 'good meat'82 being placed on that same package instead. Which trademark conveys the most accurate information to consumers? And which one appears more appealing? Recent market surveys support the suggestion that sales for

75 ibid.

76 Johnson (n 68) 2.

77 Jihee Hwang and others, 'Factors Affecting Consumers' Alternative Meats Buying Intentions: Plant-Based Meat Alternative and Cultured Meat' (2020) 12(14) Sustainability $<$ https://doi.org/10.339o/su12145662> accessed 21 March 2021.

78 Steph Tai, 'Legalizing the Meaning of Meat' (2020) 51(3) Loy U Chi L J 743-89. Also, there is a cautionary tale in the promotion of cultured meat within one homogeneous cultural group that might lead to the appearance or reality of 'cultural imperialism': Sebo (n 65) 171 (with further references).

79 A similar discussion has been taking place around milk: Iselin Gambert, 'Got Mylk? The Disruptive Possibilities of Plant Milk' (2019) 84(3) Brook L Rev 8o1-72.

80 For a discussion about different concepts of food quality, see Mariela Maidana-Eletti, 'Trade in Foodstuffs: The Impact of EU Internal Market Rules on Swiss Food Legislation' in Mariela Maidana-Eletti and Carly Toepke (eds), Recht und Gesellschaft (Schulthess 2014) 141, 144-45.

81 United States Patent and Trademark Office (USPTO) BlueNalu Inc, Application Nr 88095389 (28 August 2018) <https://uspto.report/TM/88095389> accessed 22 December 2021. This trademark has been now abandoned.

82 USPTO Eat Just Inc, Application Nr 90161003 (4 September 2020) < https://uspto.report/ $\mathrm{TM} / 90161003>$ accessed 22 December 2021. This trademark is active. 
cell-based seafood bearing the second trademark on its labelling would be higher. ${ }^{83}$ The choice of trademarked words is, thus, crucial.

\section{Legal Ontologies and Trademark Rights as Enhancers of Food Labelling}

In essence, marks are defined as signs used to distinguish goods and services during the course of trade. Marks offer businesses the opportunity to establish an exclusive link between a product and the consumer through a distinctive sign. Trademarks serve many functions, among which the guarantee of origin, quality, communication and advertising are of a protected nature. As such, in cases where a recognised mark is used, consumers will assume that a given product is safer or of higher quality. Hence, public perception is paramount in establishing that a mark represents a connection between the trademark owner and the goods for which that trademark is used, ${ }^{84}$ as it indicates that certain goods have already given the consumer a satisfactory experience, and that bore the same mark.

\subsection{Establishing a Legal Threshold: The Functionality of Trademarks}

Trademarks have two main functions: (1) to guarantee the origin of products, and (2) to guarantee the quality of products. ${ }^{85} \mathrm{~A}$ trademark identifies a product as satisfactory and stimulate further purchases by consumers, that is, it allows consumers to distinguish one good from another. A trademark is not merely a sign of goodwill, but it embeds 'agency for the actual creation and perpetuation of good will, imprinting upon the public mind an anonymous and impersonal guarantee of satisfaction. ${ }^{86}$ Hence, the effectiveness of a trademark's selling power is directly proportional to its degree of distinctiveness. The more distinctive a mark, the deeper its impress upon the public consciousness, and the greater its need for protection against vitiation.

83 As presented in peer-reviewed studies on consumer acceptance of cell-based meats; see Rubio and others (n 6); Hallman and Hallman (n 21).

84 This notion of trademark has barely changed since the turn of the 19th Century: Frank Schechter, 'Rational Basis for Trademark Protection' (1927) 40 Harv L Rev 813-33, 816.

85 It is now understood that a trademark can also function as means of advertising and investing: Neil Wilkof and Eleanor Wilson, "Turn and Face the Strange": How Changes in Commercial Circumstances Determined the Outcomes in Scandecor and Starbucks (HK)' (2018) 13(1) JIPLP 36-48, 37.

86 Schechter (n 84) 818-19. 
From a Law and Economics lens, Frank Schechter identified four main principles arising out of the theory of origin:

(1) the value of trademarks lies in their selling power and so must be afforded sufficient protection;

(2) the selling power of a trademark is determined by consumers' perception of the merits, uniqueness and singularity of the goods;

(3) the distinctiveness of a trademark is affected by its use in related and non-related products; and

(4) the degree of protection afforded depends on the actual differentiation from other marks. ${ }^{87}$

Accordingly, the main rationale behind trademark protection is the need to preserve the distinctive function of a mark, so as to ensure that consumers will repeat their purchase choices in cases where they are able to associate a given mark with a satisfactory product. Conversely, the guarantee of quality function refers to trademarks as identified satisfactory sources that increase the selling power of the goods bearing them. The creation and retention of custom acts as the primary purpose of trademarks, for which preservation of uniqueness is paramount to the trademark owner. Precisely because trademark owners are not legally bound to offer a constant level of quality in the goods bearing the mark, there is an increased risk of conveying misleading information to consumers, which in turn appears to be the main rationale behind trademark regulation that aims at preventing deceptive practices. ${ }^{88}$

\subsection{Trademarks and Public Policy Imperatives}

Thus, in cases where the intrinsic rationale of IP rights is based on the recognition of private interests to ensure their protection - such as the right of trademark holders to be identified by their customers - their extrinsic balance is found in the social function of IP rights in protecting consumers. ${ }^{89}$ On the one hand, trademarks provide consumers with the ability to make purchasing decisions based on accurate information in the marketplace. On the other hand,

$87 \quad$ ibid 831 .

88 Irene Calboli and Christine Haught Farley, "The Trademark Provisions in the TRIPS Agreement' in Carlos Correa (ed), Intellectual Property and International Trade: TRIPS Agreement (3rd edn, Wolters Kluwer 2016) 157, 162.

89 Nathalie Devillier and Ted Gleason, 'Consistent and Recurring Use of External Legal Norms: Examining Normative Integration of the FCTC Post-Australia-Tobacco Plain Packaging' (2019) 53(4) JWT 533, 559. 
trademarks allow their holders to extract economic value from the exclusive rights derived thereof. Consumers will tend to purchase a good bearing a mark that they can associate with previous satisfactory experiences without effectively knowing whether that product complies with the high standards it used to. Arguably, the quality function of a trademark imposes a de facto higher standard of compliance on its owner. Any failure to reach this threshold would lead to a loss of distinction and, conversely, of consumer trust and product sales. Attributing a function to trademarks is critical, since it will serve as a parameter to establish what rights are conferred to trademark holders, and whether exceptions to those rights or special requirements on their use may apply.

Ultimately, the legal monopoly granted by trademark protection aims at benefiting society in general. ${ }^{90}$ Precisely because trademarks are equipped with an ability to accommodate higher public policy imperatives, such as the achievement of a sustainable blue economy to mitigate risks associated with climate change, food insecurity and lack of animal welfare, it is necessary to design responsive regulation that reflects these socio-legal realities. Recent WTO reports on Australia - Plain Packaging shed light on the interpretation of international trademark law, and how domestic regulation can be calibrated to ensure compliance with international legal standards, while advancing societal interests. We turn to analyse these reports, and their implications for ocean governance, below.

\section{Special Requirements Under Article 20 of the Agreement on Trade-Related Aspects of Intellectual Property Rights After Australia - Plain Packaging}

While WTO disputes typically involve only a piece of legislation that is alleged to have violated a covered agreement, the disaggregation of individual measures from their broader legislative context risks ignoring the political compromises negotiated to advance legal reform. ${ }^{91}$ As seen with the previous example provided by the US Cattlemen's Association, the purposed aim of potential

9o Addressing in general the economics of IP rights and competition policy: Joseph Drexl, Research Handbook on Intellectual Property and Competition Law (Edward Elgar 2008) $35^{-36 .}$

91 Graeme Dinwoodie and Rochelle Dreyfuss, A Neofederalist Vision of TRIPS: The Resilience of the International Intellectual Property Regime (OUP 2012) 116-17. 
labelling legislation that restricts the use of the word 'meat' to conventionally produced meats is to reduce the likelihood of consumer confusion and misrepresentation. Arguably, there is a protectionist argument to be made in favour of such meat labelling initiatives, whereby the aim is not to guarantee consumer protection, but to prevent market access. The hypothesis posited here is that labelling measures applicable to cell-based meats will comply with the 'justifiability test' under Article 20 TRIPS in cases where their ultimate objective is that of addressing an exceptionally grave global problem, such as the inevitability of climate change. It further contends that that different levels of granularity in domestic labelling legislation will directly and proportionally affect the spectrum of rights afforded to trademark owners competing in the cell-based meat market. We test the hypothesis below.

\subsection{General Remarks About Article 20 of the Agreement on Trade- Related Aspects of Intellectual Property Rights}

Article 20 TRIPS refers to special requirements that may affect the use of trademarks in the course of trade. ${ }^{92}$ It applies in cases of goods bearing a mark that are allowed to be placed in a given market upon fulfilment of special domestic requirements. Specifically, it imposes on Members the duty to refrain from requiring foreign trademark holders to link their marks to those of local producers, resulting in a considerable reduction of Members' autonomy to legislate..$^{93}$

Article 20 has been first relied on in the course of dispute settlement proceedings in Indonesia - Autos. ${ }^{94}$ Most recently, Article 20 was interpreted by the Panel and the Appellate Body in Australia - Plain Packaging. ${ }^{95}$ TheWTO disputes were brought against Australia initially by Ukraine ${ }^{96}$ and Honduras. ${ }^{97}$ The former initiated but later suspended proceedings, which subsequently lapsed. ${ }^{98}$

92 This Section is based on Mariela de Amstalden, 'Article 2o' in Peter-Tobias Stoll and Holger Hestermeyer (eds), Commentaries on World Trade Law: Volume 6 - Trade-Related Aspects of Intellectual Property Rights, Fully Revised Second Edition (Brill forthcoming).

93 Dinwoodie and Dreyfuss (n 91) 36.

94 WTO, Indonesia - Certain Measures Affecting the Automobile Industry, Report of the Panel (23 July 1998) WT/DS54/R, WT/DS55/R, WT/DS59/R, WT/DS64/R.

95 Australia - Plain Packaging (Panel) (n 18); Australia - Plain Packaging (Appellate Body) (n 18).

96 WTO, Australia - Certain Measures Concerning Trademarks and Other Plain Packaging Requirements Applicable to Tobacco Products and Packaging, Request for Consultations by Ukraine (15 March 2012) WT/DS434/1.

97 WTO, Australia - Certain Measures Concerning Trademarks and Other Plain Packaging Requirements Applicable to Tobacco Products and Packaging, Request for Consultation by Honduras (10 April 2014) WT/DS 435/1.

98 WTO, Australia - Certain Measures Concerning Trademarks and Other Plain Packaging Requirements Applicable to Tobacco Products and Packaging Australia-Plain Packaging, Note by the Secretariat (30 June 2016) WT/DS434/17. 
Requests for consultations followed by Cuba, ${ }^{99}$ the Dominican Republic 100 and Indonesia ${ }^{101}$ pursuant to the rules of the Dispute Settlement Understanding (DSU). In essence, the complainants argued that Australia's plain packaging schemes violated Article 20 as it contained special requirements that unjustifiably encumbered the use tobacco related trademarks in the course of trade. ${ }^{102}$ Australia justified the impugned measures referring to public health objectives and compliance with other international obligations, such as the Framework Convention on Tobacco Control (FCTC). ${ }^{103}$ Australia's plain packaging measures are part of a comprehensive tobacco control program that includes, among others, banning on tobacco advertising and promotion, mandatory textual and graphic warnings on tobacco packages, and taxation of tobacco products. ${ }^{104}$ Ultimately, the Panel concluded inter alia that the complainants had not demonstrated that the TPP measures are inconsistent with Article 20 TRIPS on the basis that the measures unjustifiably encumber the use of tobacco trademarks in the course of trade. The Appellate Body upheld these findings. ${ }^{105}$ Notably, the novel interpretation of Article 20 TRIPS in AustraliaPlain Packaging demonstrates prima facie that the TRIPS trademark regime is vested with enough flexibility to accommodate relevant societal interests while safeguarding the protection of IP rights. ${ }^{106}$ It also sheds light onto its potential

99 WTO, Australia - Certain Measures Concerning Trademarks and Other Plain Packaging Requirements Applicable to Tobacco Products and Packaging, Request for Consultation by Cuba (7 May 2013) WT/DS458/1.

100 WTO, Australia - Certain Measures Concerning Trademarks and Other Plain Packaging Requirements Applicable to Tobacco Products and Packaging, Request for Consultation by the Dominican Republic (25 September 2013) WT/DS467/1.

101 WTO, Australia - Certain Measures Concerning Trademarks and Other Plain Packaging Requirements Applicable to Tobacco Products and Packaging, Request for Consultation by Indonesia (7 May 2013) WT/DS458/1.

102 Analysing previous legal procedures that led to the request for consultations before the WTO Dispute Settlement System (DSU): Wolf Meier-Ewert, 'The WTO Disputes Regarding Tobacco Plain Packaging - Selected TRIPS Findings from the Panel Stage' in Christopher Heath and Anselm Kamperman Sanders (eds), Intellectual Property and International Dispute Resolution (Kluwer Law International 2019) 1-33.

103 World Health Organisation (WHO) Framework Convention on Tobacco Control (adopted 21 May 2003, entered into force 27 February 2005) 2302 UNTS 166 (FCTC).

104 Explaining in detail Australia's plain packaging scheme: Andrew Mitchell and Mariela Maidana-Eletti, 'Plain Packaging in Australia: Implications for Trademark Rights Under the TRIPS Agreement and the Paris Convention' (2014) 10 Anuario Andino de Derechos Intelectuales 205, 295-97.

105 Australia - Plain Packaging (Appellate Body) (n 18) paras 7.11-13.

106 The conclusion reached by the Panel coincides with the prevailing legal academic stand about the compatibility of plain packaging measures with Article 20 TRIPS: among others, Mitchell and Maidana-Eletti (n 104); Mark Davison and Patrick Emerton, 'Rights, Privileges, and Justifiability: Article 20 of TRIPS and Plain Packaging of Tobacco' (2014) 
impact on domestic trademark legislation (and jurisprudence) when weighing restrictions on the use of trademarks against other societal interest interests. ${ }^{107}$ We now turn to identify the elements contained in Article 20 TRIPS.

\subsection{Elements of Article 20 of the Agreement on Trade-Related Aspects of Intellectual Property Rights}

4.2.1 'Special Requirements'

In order to determine what constitutes 'special requirements' under Article 20 TRIPS, the Panel in first considered its ordinary meaning, taken in its context and in light of its object and purpose and that of the TRIPS Agreement in general. ${ }^{108}$ It concluded that the term 'special requirements' refers to a condition that: (1) must be complied with; (2) has a close connection with or specifically addresses the 'use of a trademark in the course of trade'; (3) is limited in application; and (4) may include a requirement not to do something, in particular a prohibition on using a trademark. ${ }^{109}$ In other words, a 'special requirement' for the purposes of Article 20 TRIPS requires that the impugned measure is mandatory, specific and has a direct effect on the use of a trademark in the course of trade.

\subsection{2 'Encumbrance'}

There will only be a violation of Article 20 TRIPS in cases where special requirements 'encumber' the use of a trademark, to the extent that they would restrict such use 'in the course of trade.'110 The Panel interpreted the term 'encumbered' as equal to 'hinder' or 'hamper', holding that a prohibition on the use of a trademark amounts to an encumbrance to the greatest possible extent. ${ }^{111}$ Hence, encumbrances arising from special requirements within the meaning of Article 20 TRIPS may display an ample range with different levels of restrictions: from limited encumbrances, like those found in Article 20 TRIPS first and second sentences, to more extensive encumbrances, like the prohibition on the use of a trademark. ${ }^{112}$ By doing so, the Panel is asserting its view that

29(3) American University International Law Review 505-80; Tania Voon, 'Flexibilities in WTO Law to Support Tobacco Control Regulation' (2013) 39(2-3) AJLM 199-217.

107 Such as the protection of public morals, consumers or, indeed, public health: Benn McGrady, 'Tobacco Plain Packaging and the Expanding Role of the WTO in Regulatory Oversight' (2020) 37(1) Australian Yearbook of International Law Online 76-88.

108 Australia-Plain Packaging (Panel) (n 18) paras 7.2221 ff.

109 ibid para 7.2231.

110 ibid paras 7.2234-5.

111 ibid para 7.2263 .

112 ibid para 7.2239. 
WTO law offers sufficient flexibility to accommodate the demands of diverse legal systems and concepts.

\subsection{3 'Use of a Trademark'}

The term 'use' in Article 20 TRIPS has been interpreted by the Panel as referring to an objective fact of use in the course of commercial activities. While acknowledging that trademark functions of product differentiation and promotion of qualities may overlap in practice, the Panel stated that the term 'use' shall not be limited on the basis of a notion of function or purpose thereof. ${ }^{113}$ This conclusion is in line with WTO precedent in US - Section no(5) Copyright Act ${ }^{114}$ and Canada-Pharmaceutical Patents, ${ }^{115}$ whereby it is for the rights holders to decide whether and to what extent to exploit or make use of their exclusive rights to extract economic value from those rights in the marketplace.

In line with international trademark law theory, the term 'use' under Article 20 TRIPS is not limited to the use of trademarks for the sole specific purpose of distinguishing the goods and services of one undertaking from those of other undertaking. ${ }^{116}$ As presented earlier, distinctiveness is only one of the numerous functions attributed to trademarks.

\subsection{4 'In the Course of Trade'}

The Panel shed light in what is to be understood under the term 'in the course of trade' as provided for in Article 2o TRIPS. Considering once again the ordinary meaning of the term, the Panel concluded that the term covers broadly the process relating to commercial activities, and goes beyond the understanding of 'trade' as only 'buying and selling.'117 This clarification is of particular importance, since trademarks continue to perform functions after the completion of the act of sale, such as differentiation and advertising. ${ }^{118}$

\subsection{5 'Unjustifiabily'}

Once it has been established that special requirements encumber the use of trademarks in the course of trade, Article 20 TRIPS provides for an exception rule according to which encumbrances must not do so 'unjustifiably'. The term

\footnotetext{
113 ibid para 7.2284 .

114 WTO, United States - Section no(5) of US Copyright Act, Report of the Panel (27 July 200o) WT/DS16o/R, para 6.165.

115 WTO, Canada - Patent Protection of Pharmaceutical Products, Report of the Panel (7 April 200o) WTO/DS114/R, paras 7.54-5.

116 Australia - Plain Packaging (Panel) (n 18) para 7.2286.

117 ibid para 7.2261.

118 ibid para 7.2263 .
} 
has been interpreted by the Panel in Australia - Plain Packaging according to its ordinary meaning, stating that it refers to the ability to provide a justification or good reason for the relevant action or situation 'that is reasonable in the sense that it provides sufficient support for that action or situation.'119 This reading of the term 'unjustifiably' was later upheld by the Appellate Body, ${ }^{120}$ stating:

In our view, the term 'unjustifiably' in Article 20 of the TRIPS Agreement reflects the degree of regulatory autonomy that Members enjoy in imposing encumbrances on the use of trademarks through special requirements. The reference to the notion of justifiability rather than necessity in Article 20 suggests that the degree of connection between the encumbrance on the use of a trademark imposed and the objective pursued reflected through the term 'unjustifiably' is lower than it would have been had a term conveying the notion of 'necessity' been used in this provision. ${ }^{121}$

It followed by stating that the term 'unjustifiably' in Article 20 TRIPS indicates a situation where the use of a trademark is encumbered by special requirements in a manner that lacks sufficient justification or reason to support the resulting encumbrance. ${ }^{122}$ Conversely, there may be circumstances in which good reasons exist to support the application of encumbrances on the use of a trademark in a justified manner. ${ }^{123}$ In these case, the justifiability test will find application.

\subsection{The Justifiability Test}

These reasons are not specified under Article 20 TRIPS, and thus the Panel conducted a contextual interpretation based on the Preamble to the TRIPS Agreement, Article 7 TRIPS (Objectives), and Article 8 TRIPS (Principles). ${ }^{124}$ It concluded by recognizing that there may be legitimate reasons for a Member to encumber the use of trademarks by special requirements, and by stating that the term 'unjustifiably' defines the applicable standard for the permissibility of such encumbrances. ${ }^{125}$ The Appellate Body agreed with the Panel,

\footnotetext{
119 ibid para 7.2395.

120 Australia - Tobacco Plain Packaging (Appellate Body) (n 18) para 6.645.

121 ibid para 6.647.

122 Australia - Plain Packaging (Panel) (n 18) para 7.2395.

123 ibid para 7.2395.

124 ibid paras 7.2398-7.2404.

125 ibid para 7.2405 .
} 
considering that measures aiming at the protection of public health and nutrition fall within the scope of measures specifically contemplated by the TRIPS Agreement. ${ }^{126}$ In other words, Article 20 TRIPS establishes a justifiability test for the application of measures that, among others, strive to achieve legitimate societal interests - such as those established in Article 8 TRIPS. ${ }^{127}$

Based on this new justifiability test, ${ }^{128}$ an examination of whether the use of a trademark in the course of trade is being unjustifiably encumbered by special requirements requires consideration of three factors ${ }^{129}$ :

(1) nature and extent of the encumbrance resulting from the special requirements, bearing in mind the legitimate interests of trademark owners in using its trademark in the course of trade, allowing it to fulfil its intended function;

(2) the reasons for which the special requirements are applied, including any societal interests they intend to safeguard; and

(3) whether these reasons provide sufficient support for the resulting encumbrance. ${ }^{130}$

An assessment about the balance among these factors is to be conducted on a case-by-case basis. ${ }^{131}$ This novel interpretation and application of Article 20 TRIPS suggest that the provision is now included in the WTO's public interest exceptions - alongside Article XX GATT, ${ }^{132}$ Article XIV GATS, ${ }^{133}$ and Article 2.2 TBT Agreement, ${ }^{134}$ thus further developing the doctrine of 'weighing

126 Australia - Tobacco Plain Packaging (Appellate Body) (n 18) para 6.649.

127 Art 8 TRIPS reads: 'Members may, in formulating or amending their laws and regulations, adopt measures necessary to protect public health and nutrition, and to promote the public interest in sectors of vital importance to their socio-economic and technological development, provided that such measures are consistent with the provisions of this Agreement'.

128 Alice Marxwell, 'Plainly Justifiable? The World Trade Organization's Ruling on the Validity of Australia's Plain Packaging Under Article 2o of the TRIPS Agreement' (2019) 14(1) Asian Journal of WTO and International Health Law and Policy 116-45.

129 Australia - Plain Packaging (Panel) (n 18) para 7.2430.

130 ibid para 7.2430.

131 ibid para 7.2431.

132 General Agreement on Tariffs and Trade, Marrakesh Agreement Establishing the World Trade Organization (15 April 1994) Annex 1A, 1867 UNTS 187 (GATT).

133 General Agreement on Trade in Services, Marrakesh Agreement Establishing the World Trade Organization (15 April 1994) Annex 1B, 1869 UNTS 183 (GATS).

134 Agreement on Technical Barriers to Trade, Marrakesh Agreement Establishing the World Trade Organization (15 April 1994) Annex 1A, 1868 UNTS 120 (TBT Agreement). 
and balancing'135 introduced by the Appellate Body in Korea - Beef ${ }^{136}$ almost two decades ago. Indeed, in Australia - Plain Packaging, the Panel conducted a balancing test between public health concerns underlying plain packaging measures on the one hand (nature), and their implications on the use of trademarks in the course of trade on the other (extent), in order to assess whether there is sufficient support for the resulting encumbrance. ${ }^{137}$ This weighing and balancing exercise, appealed by Honduras, was later upheld by the Appellate Body. ${ }^{138}$ The Panel continued its test by establishing that the rationale behind the adoption of plain packaging measures was undisputed in as far as they address an exceptionally grave domestic and global health problem that involves high levels of preventable morbidity and mortality -in this case, tobacco consumption. ${ }^{139}$ It further elaborated:

The fact that these special requirements ... are capable of contributing, and do in fact contribute, to Australia's objective of improving public health by reducing the use of, and exposure to, tobacco products, suggests that the reasons for which these special requirements are applied provide sufficient support for the application of the resulting encumbrances on the use of trademarks. ${ }^{140}$

More specifically, the Panel considered three reasons to determine whether sufficient support exists:

(i) suitability: the removal of design features on retail packaging as apt to reduce the appeal of tobacco products ${ }^{141}$;

(ii) uniformity: the uniformity of the measure's features in contributing to an overall standardization of tobacco packaging and product appearance $^{142}$; and

135 For a critical view of the WTO's doctrine of 'weighing and balancing', see Csongor Istvan Nagy, 'Clash of Trade and National Public Interest in WTO Law: The Illusion of "Weighing and Balancing” and the Theory of Reservation' (2020) 23(1) JEIL 143, 144.

136 In the context of Article XX GATT, see WTO, Korea - Measures Affecting Imports of Fresh, Chilled and Frozen Beef, Report of the Appellate Body (10 January 2001) WT/DS161/AB/R and WT/DS169/AB/R.

137 Australia - Plain Packaging (Panel) (n 18) paras 7.2590-1.

138 Australia - Tobacco Plain Packaging (Appellate Body) (n 18) para 6.681.

139 Australia-Plain Packaging (Panel) (n 18) para 7.2592.

140 ibid para 7.2592.

141 ibid para 7.2593 .

142 ibid para 7.2594 . 
(iii) global compliance: Australia's intention of giving effect to certain obligations under the Framework Convention for Tobacco Control (FCTC) through the adoption of plain packaging measures. ${ }^{143}$

Based on these considerations, the Panel concluded that the term 'unjustifiably' in Article 20 TRIPS provides Members with a degree of latitude in determining legitimate objectives and adopting measures to attain those policies, which may or may not have an impact on the use of trademarks in the course of trade, so long as the reasons sufficiently support any resulting encumbrance. ${ }^{144}$ This conclusion, too, was upheld by the Appellate Body. ${ }^{145}$

\section{The Importance of the 'Justifiability Test' for a Sustainable Blue Economy}

The legal disputes encountered in Australia - Plain Packaging provide essential guidance about the ability of international trademark law to enhance ocean governance and promote a sustainable blue economy. It does so by illustrating that it is possible to accommodate a wide range of public policy imperatives, such as the achievement of SDGs, while safeguarding intellectual property rights. Importantly, in cases where the rationale behind the adoption of measures aims at addressing exceptionally grave domestic and global problems as it is arguably the case with measures that promote sustainable development through labelling - the novel interpretation of Article 20 TRIPS reconciles the rights conferred to trademark owners to extract economic value with the right of Members to attain public policy objectives. Its implications are indeed numerous, as the development of a 'justifiability test' continues to emphasise regulatory autonomy and the ability to promote a transition from blue growth to a sustainable blue economy without encumbering on exclusive rights.

\subsection{Implications for the Labelling of Cell-Based Meats}

In particular, one of the implications is that measures banning the use of terms with a legally defined meaning - such as the term 'meat' - on the labelling of cell-based food products, and the extent to which such a ban encumbers on the legitimate interests of trademark owners, will be likely to prevent a trademark from fulfilling intended functions: that of guaranteeing origin and

\footnotetext{
143 ibid para 7.2596.

144 ibid para 7.2598.

145 Australia - Tobacco Plain Packaging (Appellate Body) (n 18) para 6.695.
} 
quality through distinctiveness. A second set of concerns relates to the rationale behind the application of special requirements, that is, whether certain policy concerns and societal interests underlie the adoption of such measures. In light of Australia - Plain Packaging, it can be ascertained that exceptionally grave domestic and global problems akin to the tobacco pandemic will enjoy a presumption of compliance with WTO. This is where a degree of latitude in ascertaining regulatory autonomy comes to bear. For example, labelling measures applying to cell-based meat and seafood that are adopted to tackle climate change, food insecurity or animal cruelty - all included as objectives in the SDG s - could be construed as reasons to address exceptionally grave domestic and global problems. The range of justifications for an encumbrance on trademark rights would fluctuate from very stringent (animal welfare concerns) to least stringent (climate change mitigation). As previously shown, all three reasons intend to dominate the legal discourse of cell-based meats and seafood. Another implication is that labelling measures will need to have sufficient support and be deemed suitable, uniform and have the intent to give effect to other relevant international obligations. The present analysis indicates that a ban on the use of the term 'meat' on labels for cell-based meat products would not be apt to reduce consumer confusion, because cell-based meats are molecularly identical their conventional counterparts. Furthermore, it is not apparent that such measures would substantially contribute in a uniform manner to levelling the information conveyed to consumers through labels. Lastly, in the absence of an international compositional standard for meat and seafood products, such as from the Codex Alimentarious Commission (CAC) or the World Organization for Animal Health (OIE), there are currently no known international obligation that a measure banning the use of the term 'meat' would intend to give effect to. As such, labelling measures that do not take into account the above considerations will be in violation of Article 20 TRIPS. In the event of the encumbrance not being justified under Article 20, Article 17 TRIPS, with its more stringent legal standard may potentially apply. ${ }^{146}$ Certainly, whether the adopted domestic measures constitute a curtailment to rights conferred to trademark owners that fall within the meaning of limited exceptions under Article 17 TRIPS will be irrelevant in cases where a violation of Article 20 TRIPS is found, because only a proportionality assessment, that is, a 'justifiability test' will be required to establish compliance with WTO law.

146 Mariela Maidana-Eletti, 'Market Access and Trademark Protection in the WTO Regime' in Helena Zaugg and Lea Schläpfer (eds), Recht und Gesundheit (Schulthess 2013) 69-85, 80. 


\subsection{Concluding Remarks}

Societies differ in their regulatory approaches to accommodate their own values and morals. In cases where the rationale behind the adoption of measures aims at addressing exceptionally grave domestic and global problems - as it is arguably the case with measures that promote sustainable development through labelling -, the recent interpretation of Article 20 TRIPS reconciles the rights conferred to trademark owners to extract economic value with the right of Members to attain public policy objectives. A case study of cell-based meat and seafood emphasises the importance of smart regulatory design in anticipating potential legal risks and challenges in international (IP) fora, and highlights the complexity of the issues at hand. As put forth above, the innovative technology underlying the emergence of cell-based seafood has the potential to address the negative externalities associated with current practices in ocean governance. Cell-based seafood - in its developmental stage at the time of writing - displays positive attributes that makes it a viable alternative food and feed option to reduce pressure on marine ecosystems. This paper argued that trademark rights have an undeniable potential to promote sustainable products that tackle pressing global challenges, such as the transition towards a sustainable blue economy to improve ocean governance. In doing so, this paper has laid the groundwork to discuss further the impact of innovative technologies in the global supply chain and how cell-based meats and seafood may provide an acceptable and efficient method to avert the challenges associated with industrial faming, aquaculture, and marine capture, while at the same time feeding an increasing world population fresh and healthy seafood.

It turns out, words matter. They carry a 'semantic field of potential meanings which is partly governed by a social code and partly individualized by the unique features of whoever utters or interprets the word.' ${ }^{147}$ Indeed, what we consider as food matters. It matters in our regulatory frameworks, in our cultural perceptions, in our social acceptance of new technologies and, eventually, it matters for the urgent transformation needed in our global food supply chain. The role of law in producing and shaping our interpretation of reality is vital in concretising these elements of the material world. ${ }^{148}$ The emergent tendency for de-globalization might impact the speed of cell-based meat and seafood development, the effects of which are still unknown. In particular, the

\footnotetext{
147 Robert Scholes, 'Language, Narrative, and Anti-Narrative' (1980) 1(7) Critical Inquiry 204, 206-07.

148 David Delaney, 'Making Nature/Marking Humans: Law as a Site of (Cultural) Production' (2001) 91(3) Annals of the Association of American Geographers 487, 489.
} 
ethical and cultural consequences of replacing conventional meat and seafood products with cell-based equivalents merits further research.

\section{Biographical Note}

Dr. iur., LL.M., MLaw, Lecturer in Intellectual Property Rights and Innovation Law, Birmingham Law School, University of Birmingham; Visiting Research Fellow, Scottish Centre for IT and IP Law (SCRIPT Centre), University of Edinburgh.

\section{Acknowledgments}

I owe my gratitude to Burkhard Schafer, Professor of Computational Legal Theory at the University of Edinburgh and Director of the SCRIPT Centre, whose intellectual prowess inspired core ideas presented in this paper, the central thesis of which grew out of numerous conversations since 2018. Thanks also to Markus Wagner, Professor of Law at the University of Wollongong for thoughtful engagement and insightful comments about this paper.

\section{Disclaimer}

A large part of this research was presented at the 9th PEPA/SIEL Conference, hosted by the Hebrew University of Jerusalem Faculty of Law, 17-19 May 2020, and at the 2020 LEAP Conference, University of Oxford, 11 December 2020. All opinions expressed here and any errors are my own. 